\title{
The European Patent and Its Courts: An Uncertain Prospect and an Unfinished Agenda
}

\author{
Hanns Ullrich
}

Published online: 29 January 2015

(C) Max Planck Institute for Innovation and Competition, Munich 2015

This year the "Agreement on a Unified Patent Court", which 25 out of the 28 Member States of the European Union have concluded on 19 February $2013^{1}$ is expected to be ratified by at least 13 of its signatory States (including France, Germany, the United Kingdom) and to enter into force three months after the deposit of the 13th instrument of ratification. At the same time EU Regulation $1257 / 2012$ on the creation of unitary patent protection in the area of enhanced cooperation, ${ }^{2}$ which has been in force for more than a year, will enter into application. While this will not be the last act in more than half a century of efforts to establish a full-fledged system of uniform patent protection in the EU, it will be hailed by the patent community - and not only by the European patent community as a big step forward. The Agreement holds, indeed, two great promises. They are of different kind, but both to the same effect of guaranteeing uniformity of patent protection across national borders.

On the one hand, in its Arts. 25 to 30, the Agreement provides for a full set of rules of substantive law regarding infringement of and the exceptions from the exclusive patent right. These rules apply to all European patents, directly as regards European patents, which are valid only in designated Member States, and indirectly by virtue of Art. 5 Reg. 1257/2012 as regards European patents having unitary effect throughout the area of enhanced cooperation.

On the other hand, the Agreement ensures uniform enforcement of these two types of European patents by attributing to the Unified Patent Court (UPC) an

\footnotetext{
${ }^{1}$ OJEU 2012 C 175,1; non-signatory States are Poland and Spain. Croatia joined the EU only in July 2013.

2 OJEU 2012 L $361,1$.

H. Ullrich $(\bowtie)$

Prof. (em.), Dr. iur., MCL (NYUniv.); visiting professor

College of Europe, Brugge, Belgium; affiliate researcher Max Planck Institute for Innovation and

Competition, Munich, Germany

e-mail: hanns.ullrich@ip.mpg.de
} 
exclusive jurisdiction over litigation on the infringement and/or the invalidation (revocation) of European patents. The UPC, while declared to be "a court common to the Contracting Member States and thus subject to the same obligations under Union law as any national court of the Contracting Member States" (Art. 1(2)), is set up as a judiciary, which by its organization and composition operates as an international court. It will have its own statute, administration and budget, hopefully fed from its own income (Art. 37). Aside of a Central Division, its Court of First Instance will have local and regional divisions in the Member States separate from the national judiciaries, and it will have a Court of Appeal as a court of last instance. The UPC will adjudicate according to the provisions of the Agreement and of its own Rules of Procedure; it will grant remedies as foreseen by the Agreement, and its decisions will have effect throughout all the (national) territories, which are actually covered by a European patent.

Over and above the uniformity of the rules on infringement and of the enforcement of patent protection across national borders, the Agreement promises other advantages. Thus, as compared to the patent with unitary effect, it enhances the position of the classic European patent by giving the same effect to all the national patents resulting from the European grant in all the designated Member States. This way, it will upgrade the European bundle of national exclusive rights to an interesting alternative to the unitary patent, and this not only in case protection is not needed in respect of the entire territory of enhanced cooperation. A more salient feature of the Agreement is the way it combines decentralization of infringement litigation at local or regional divisions with centralization of invalidity (revocation) proceedings by sort of an optional concentration at the Central Division. It thus strikes a balance between the patentee's interest in legal certainty and effective enforcement and third parties' interests in full and fair defense before a convenient court. Since, in addition, the UPC's panels are composed of legally trained and technically trained judges - regularly so at the Central Division and even at the Court of Appeal, at local and regional divisions only in case a counterclaim for revocation is brought - and since the jurisdiction of the UPC is limited to patent disputes, the overall concept of the Agreement is the creation of a judiciary, which is tailor-made for (international) patent litigation. This is the raison d'etre of the UPC and, together with the transaction cost savings resulting from the one-stopshop principle of internationally exclusive jurisdiction, its second main advantage. In sum, the Agreement's promises are for uniformity of protection, unity and effectiveness of enforcement, and for patent specificity of decision finding, thus for reliability of judicial practice.

Unfortunately, this promising prospect catches only part of the reality. Despite its exclusive jurisdiction, the UPC will have no monopoly over European patent litigation. Rather, it will have to share its role with national courts

- first, of EPC Contracting States, which are not Members of the EU;

- second, of EU Member States, which do not participate in enhanced cooperation;

- third, of EU Member States, which do not adhere to the Agreement, either not at all or because they have not yet ratified the Agreement; 
- fourth, of all Contracting Member States during a transitional period of seven years, extendable by another seven years (Art. 83(1), (5));

- fifth, of all Contracting Member States as regards European patents whose proprietors have "opted out" of the exclusive competence of the UPC (Art. 83(3)).

It is true that the latter two transitional rules apply only to litigation over classic European (bundle) patents, not to litigation on the European patent with unitary effect. However, it is also true that for both types of European patents the substantive rules regarding patentability, infringement, exceptions, and revocation are the same. Therefore, any divergences of interpretation by the UPC or by national courts will affect the position of both. It is, indeed, not to be expected that all these national courts will align their jurisprudence on that of the UPC. Rather, they will find themselves in a competitive relationship both with the UPC and among themselves because they need to attract business. Such judicial competition, which became the more pronounced between national courts the more likely the establishment of the UPC became, will not only concern the efficiency of case management or the technical quality of decision-making. It will also produce divergences of the interpretation and/or of the application of substantive law.

As of yet the UPC's schedule of fees is not known. Clearly, however, considerations of cost will influence the parties' choice of courts, particularly so if the cost savings resulting from the one-stop-shop concept risk to be more than offset by the increased value of disputes before the UPC, and/or by costs shifting to fees for lawyers, to time lost and to collateral expenses (translation, travelling, etc.). Moreover, even if litigation comes to be concentrated before the UPC, uniformity of judicial practice will only be ensured at the level of the Court of Appeal. Due to minimum workload requirements (Art. 7(3)-(4); Art. 8(2)-(3)) and financing rules (Art. 37(1) sub-para. 2), local divisions will have to attract cases, and, therefore, will tend to develop their own judicial practice, possibly in accordance with national legal or judicial tradition. The result will be possibilities of forum shopping, which as such are common for most national judicial systems, but which might take on more importance under a unified court system covering an internal market composed of many national territories.

In addition to the risks of insufficient uniformity of the rulings of the various courts, and possibly of the divisions of the Court of First Instance, the UPC will have to face problems, which are inherent in its structure or a result of the way it has been set up. The strict limitation of its competence to litigation on infringement and revocation of patents (including only counterclaims concerning license defenses, Art. 32(1) lit. (a-h)) combined with the technical orientation of its composition leave the UPC ill equipped for deciding on matters of the laws of contract or property, which may arise as incidental points, or for dealing with broader contextual questions, such as issues of competition law, European and international trade law, human rights law or rules of market regulation, which all have become ever more relevant for patent protection. More generally, the relationship between the substantive rules of the Agreement and EU law as regards both general EU law 
and the rules of Reg. 1257/2012 is far from clear, and so is the relationship between the European Court of Justice and the UPC.

Moreover, in dealing with these problems and in fulfilling its role in general, the UPC will have to overcome a more profound problem, namely its democratic deficit. The Agreement has been submitted to the European Parliament, but has never been deliberated by it, since it has been concluded by Member States as an international non-EU instrument. National parliaments, which are called upon to ratify it, will not be able to deliberate on its provisions either, not as regards its rules of substantive patent law, not as regards its institutional and organizational set-up, and not as regards its rules on remedies or on procedure. They will have to ratify or refuse it as a whole block. It is, in fact, an instrument essentially made by the European and international patent communities themselves. Given the highly increased number and, indeed, importance of patents, the multiple functions patents have taken on and the many controversies surrounding patent protection from patent "trolls" to standard essential patents or to the various forms of extending protection for pharmaceuticals and to the need of continuous adaptation of patent protection to the changing technological, economic and societal environment - overcoming that democratic deficit will be the true challenge for the UPC.

Whereas, by virtue of its rules and due to its institutional structure, the UPC will provide full, fair and independent judicial protection in post-grant litigation on infringement and revocation of European patents, there is no counterpart to it ensuring such judicial protection in respect of the grant itself or of its being refused. It is true that under the European Patent Convention (EPC) the decisions of the EPO's Receiving Sections, Examining Divisions, and Opposition Divisions are subject to review upon appeal to the Boards of Appeal (Arts. 21, 106). During their term of office, the technically or legally qualified members of these Boards are independent in the sense that they may not at the same time be members of the administrative sections or divisions, are not "in their decisions ... bound by any instructions and shall comply only with the provisions of the Convention" (Art. 23(2)-(3)), and may not be removed from office during their term, except on serious grounds (Art. 23(1)). ${ }^{3}$ However, they remain members of the staff of the European Patent Organization, are appointed by the Administrative Council on proposal by the President (Art. 11(3)) for a limited period of time of five years (Art. 23(1)), and are subject to the disciplinary authority of the Administrative Council (Art. 11(4)). The Council may exercise this authority (only) upon proposal by the President (Art. 10(1), lit. h). ${ }^{4}$ Upon lapse of their term, Board members may be reappointed by the Council after the President has been consulted. ${ }^{5}$ The EPC does not specify the grounds for renewal or non-renewal. In case a member is not reappointed, the

\footnotetext{
3 In German "schwerwiegende Gründe", in French "motifs graves".

4 Pignatelli and Irmscher in: Benkard, Europäisches Patentübereinkommen, Art. 12, annot. 19 (2nd edn. Munich 2012).

5 Pursuant to Braendli, in: Münchner Gemeinschaftskommentar, Art. 11, annot. 38 (24th supp. Cologne 2000), the Council has no way of taking the initiative for reappointment itself, so de facto it is the President, who makes the proposal.
} 
Statute for the staff provides for that she/he will be (re-)integrated into the general service. $^{6}$

The problems associated with the hybrid status of the members of the Boards of Appeal between an independence in the exercise of their office and their status as members of the general staff of the Organization has become apparent in a recent decision of the Enlarged Board of Appeal. ${ }^{7}$ The Enlarged Board had been seized by an appeal brought pursuant to Art. 112a EPC against a decision of a Technical Board of Appeal, but then was confronted with an objection made according to Art. 24(3) EPC against the impartiality of its own Chairman on the ground that formerly he had been a high ranking official of the EPO with broad responsibilities for the administrative practice of the Office, and that, as a VicePresident in charge of Directorate General 3 (Appeals) he was currently member of the Management Committee of the President. While the circumstances of the case point to an - apparent or real - conflict of offices, which may not be typical of the composition of the Technical Boards of Appeal, the Enlarged Board was faced with the task of drawing a line between judicial and general responsibilities of its Chairman. In fulfilling this task, the Enlarged Board was led to discuss the fundamental problem, which is the absence of an institutional separation of judicial review from the administrative activities of the EPO, which the Boards are supposed to control.

As such, the problem is generally known. It is due to the fact that, at the time of the negotiation of the EPC, the Contracting Parties hesitated to establish a judicial structure, which might anticipate on or affect the later establishment of a court system having broader jurisdiction over industrial property disputes. A proposal made by the President in 2004 to give the EPO's Boards of Appeal an organizational autonomy by establishing a sort of third judicial pillar within the Organization aside of the Administrative Council and of the Office has not found sufficient political support. ${ }^{8}$ However, the problem remained virulent even though constitutional courts, which have been seized several times on grounds of lack of fair trial, acknowledged the quasi-judicial nature of the EPO's Boards of Appeal. The German Constitutional Court confirmed the compatibility of the EPO's structure and operation with principles of the rule of law and of fundamental rights without taking a closer look at the matter. ${ }^{9}$ Recently, the problem has become acute again. For one thing, new complaints have been brought before the German Constitutional Court claiming more insistently a violation of the principle of full and fair trial. For another, the President has suspended a member of a Technical Board of Appeal from office on grounds kept confidential, and he did so under circumstances, which

\footnotetext{
${ }^{6}$ See Art. 41(3) EPO Codex of Employment. However, according to its wording, Art. 41 applies only to Board members, who have been appointed from the administrative staff.

7 Decision of 25 April 2014, case R 0019/12, reprinted in this issue of IIC at doi:10.1007/s40319-0150302-7.

8 See Messerli, "Die organisatorische Verselbständigung der Beschwerdekammern des Europäischen Patentamts", in: Festschrift für Gert Kolle und Dieter Stauder, p. 441 with references (Carl Heymanns Verlag, Cologne 2005).

9 German Constitutional Court of 4 April 2001, 2001 NJW 2705; of 27 April 2010, 2011 GRUR Int. 69.
} 
have made the incident attract the attention not only of specialized Internet media, but also of the general press. ${ }^{10}$

Clearly, these are only the symptoms of the structural weakness of the EPO's system of judicial review of the decisions of the Patent Office regarding the grant or the refusal to grant a patent. The EPO has again realized the need to remedy this weakness. Apparently, it prepares new proposals for reform of the system of appeals, which it is likely to submit to the Administrative Council in 2015. A solution is, indeed, urgent and needs to be found in terms corresponding to the changed European context of the protection of patents and of industrial property in general. The fact is that there is a surprising asymmetry between the systems of judicial review regarding the granting procedures for Community trade marks, Community designs and Community plant variety protection on the one hand, and, on the other, regarding the granting procedure for European patents. Like their EPO counterparts, the Boards of Appeal of the Office Harmonization for the Internal Market (Trade Marks and Designs, OHIM) and of the Community Plant Variety Office (CPVO) take appeals from the decisions of the administrative sections or divisions of the offices. As to their organizational structure and operation, they are fully modeled upon the EPO's Boards of Appeal. Yet, despite their quasi-judicial operation, they are held by the Court of Justice of the EU not to qualify as courts and, therefore, not to be bound by strict principles of full and fair trial. ${ }^{11}$ The main reason for this qualification is that the decisions of these Boards are subject to full review by the General Court and to appeals in law to the Court of Justice. By contrast, since there is no European patent court, the Boards of Appeal of the EPO are held to be equivalent to courts, and they do consider themselves to be courts and to be bound by the principles of judicial decision-finding and decision-making. While that self-understanding of their function by the EPO's Boards of Appeal as well as their judicial engagement deserve highest respect, there is no reason why the grant or refusal of trade marks, designs or plant variety rights should benefit from a two-tier system of quasi-judicial and genuine judicial review, but the grant or refusal of patents not.

As already mentioned, patents have considerably gained in importance as regards both their various functions and their numbers. The current number of European patent applications is three times larger than was estimated originally as the average workload. This increase by itself asks for a more developed judicial review of the granting procedure. In addition, due to the unitary effect or to the enhanced uniformity and enforceability of the "bundle" of national rights flowing from the European patent grant, Europeans patents will take on more economic and legal weight, since protection will cover vastly enlarged markets, and they will do so more effectively. Moreover, the expectations and standards of judicial review have

\footnotetext{
${ }^{10}$ See Süddeutsche Zeitung of 20/21 December 2014, p. 36 "Staat im Staate". The suspension has been approved subsequently by the Administrative Council, Communique on decisions taken by the Administrative Council at its 142nd meeting concerning senior employees and appointments and reappointments to the Boards of Appeal of 12 December 2014.

11 See inter alia EU Gen Ct of 12 December 2002, case T-63/01, Procter + Gamble/OHIM, Rep. 2002 II 5255, Nos. 19 et seq.; of 23 September 2003, case T-308/01, Henkel/OHIM, Rep. 2003 II 3253, No. 34; ECJ of 13 March 2007, case C-29/05 P, OHIM/Kaul, Rep. 2007 I 2213, Nos. 49 et seq.
} 
risen. Also, the umbrella of the international status of the EPO has become less convincing as a shield from fundamental right principles, ${ }^{12}$ because European patents tend to displace national patents more and more. One need not subscribe to the thesis of an unconstitutional asymmetry existing between the "little" judicial protection, of which patent applicants may avail themselves under the EPC, and the "double" protection her/his competitors (or any third party) may obtain first via the opposition procedure and its review by the Boards of Appeal, and then by way of an action for revocation. ${ }^{13}$ The patent applicant's interest in genuine judicial review is easy enough to understand anyway. If a patent is refused, she/he loses protection once and for all at an early point of time while third parties interested in fighting the patent may choose when and how to do so, by way of opposition or later by way of an action for revocation (or only by way of a counterclaim once they are faced with an infringement suit), and they might even have a second try. There is, thus, a potential harm to innovation due to demotivation. However, if for that reason judicial review were exercised too loosely, there would also be a risk of harming innovation. There are already too many patent applications pending, and they do so for too long a time. If effective and full judicial review will take place in revocation proceedings only, it may come too late. Patent applications and, a fortiori, existing patents have a deterrent effect. Innovation rates are high in many industries, the commercial potential of many incremental technical advances frequently is clear enough to the industry concerned already at the time a patent application is filed, and the freedom of firms to operate is too important to allow postponing intense judicial control of patents until revocation proceedings are initiated by a third party (quite apart from the fact that revocation litigation is more costly than immediate opposition).

Although the existing hybrid structure of the Boards of Appeal is not satisfactory, these Boards may not simply be transformed into institutionally autonomous judicial bodies. On the one hand, the workload of the Boards of Appeal - about 2,500 cases per year - would require the establishment of too large a court where maintaining the Boards with a filtering function similar to that of the Boards of Appeal of the OHIM and the CPVO could reduce the workload of a future genuine court to manageable proportions and, at the same time, ensure efficiency of the overall granting procedure of the EPO. On the other hand, it would be hardly feasible and politically unwise to expressly or implicitly downgrade the Boards of the EPO to the current status of their counterparts at the OHIM or the CPVO, which are supposed to operate in "functional continuity" of the role of the administrative sections or divisions. ${ }^{14}$

The extension of the tasks of the Enlarged Board of Appeal by the introduction of Art. 112a EPC has not solved the dilemma, but instead made it more obvious. To the difference of Art. 112 EPC, which entrusts the Enlarged Board with the task of ensuring uniform application of the law and with clarifying points of law of

\footnotetext{
12 See supra note 9.

13 See Brox, "Einheitspatent und Einheitliches Patentgericht im europäischen Integrationsprozessverfassungsrechtliche Perspektive", 2014(6) ZGE/IPJ 89, 99 et passim.

14 See references supra note 11.
} 
fundamental importance by way of a non-adversary preliminary procedure, Art. $112 \mathrm{a}(1)$ grants a party to appeal proceedings, which has been adversely affected by the decision of a Board of Appeal, a right to file a petition for review to the Enlarged Board. However, Art. 112a(2) strictly limits the grounds for review to fundamental violations of the right to fair and correct proceedings. Instead of using Art. 112a EPC as a basis for gradually extending judicial review, the Enlarged Board tends to interpret it narrowly, in particular as regards the respect for the parties' interest in full and court-informed argument. ${ }^{15}$ While this approach may be explained in part by the exceptional character of an Art. 112a review and by concerns for keeping the Enlarged Board's workload within reasonable limits, it also mirrors the Enlarged Board's conceptualization of the role of the Boards of Appeal as not acting as genuinely judicial bodies, and it possibly also reflects management concerns regarding the overall operation of the EPO. The latter is particularly likely when the Enlarged Board acts under the guidance of a chairman, who comes from the EPO's highest ranking staff and/or may return to it, or where the majority of the Enlarged Board is so composed. There simply is a structural potential of conflict between considerations for full judicial protection and those for the overall management of the EPO. That potential is all the more worrying as the President may indirectly inform the orientation of the Board's practice by his (re-)appointment policy, should he wish to do so.

When the EPO now considers the options for a way out of the problem - possibly a return to a statute of autonomy of the Boards as proposed in 2004, possibly also a transformation only of the Enlarged Board of Appeal into a proper court of appeal it will have to face many difficulties. One is to fill the deficit of judicial review by a (EU?) court of decisions of the Opposition Division revoking or maintaining in limited form only a European patent, which enjoys unitary effect by virtue of Art. 3 Reg. 1257/2012. ${ }^{16}$ Another related difficulty is that any reform made to improve, preferably to institutionally separate judicial review, must have the consent not only of the EU Member States, but of all Contracting States of the EPC. This means that delegating parts of such review of decisions concerning the European patent in general to the European Court of Justice or integrating it altogether into the UPC will hardly be a realistic option. A more general problem is that the substantive rules determining the grant or refusal of patent protection and the substantive rules determining its revocation or confirmation are the same, namely those defining the requirements of patentability and of sufficient disclosure of the invention. Therefore, as a counterpart to the UPC, any form of enhanced, institutionally separate form of judicial review over the granting procedure should have a stature equivalent to that of the UPC. For this reason, but also as a general matter, a grand design of judicial review rather than some timid redesign at the margin ought to be aimed at. After all, the European patent is sought after mainly by applicants from outside Europe, and it represents a model for other States. It ought to do so also as

\footnotetext{
${ }^{15}$ See inter alia Zuck, "Die verfassungsrechtliche Kontrolle von Entscheidungen der Großen Beschwerdekammer des Europäischen Patentamtes wegen Verletzung des rechtlichen Gehörs", 2011 GRUR Int. 302, 304 et seq.

${ }^{16}$ See ECJ, Prise de position des Avocats généraux présentée le 2 juillet 2010 (par Av.gén. J. Kokott) sur la demande d'avis $1 / 09$ sub Nos. 71 et seq. (on file with the author).
} 
regards judicial review, be it only because European inventors apply for patents abroad and because European firms are subject to patent protection abroad. There is, therefore, a need for judicial protection everywhere, whose standards we may wish to be equal to ours. 